TOM XI (2020)

\author{
Marcin Szerle \\ (Muzeum Miasta Gdyni) \\ https://orcid.org/0000-0001-7975-8110
}

\title{
Lecznica Nadmorska w Gdyni jako przykład prywatnej inicjatywy szpitalnej okresu międzywojennego. Studium przypadku
}

Słowa klucze: Gdynia, szpital prywatny, okres międzywojenny Keywords: Gdynia, private hospital, interwar period

Zgodnie $\mathrm{z}$ definicją ujętą $\mathrm{w}$ przedwojennej encyklopedii lecznice - $\mathrm{w}$ tym domy zdrowia i sanatoria - były rodzajem klinik lub szpitali, zorganizowanych z inicjatywy prywatnej, rządowej lub samorządowej. Nie obejmowały one całokształtu lecznictwa, lecz określoną grupę chorób, co odróżniało je od szpitali tzw. powszechnych ${ }^{1}$. W popularnym ówcześnie leksykonie wyraz „lecznica” nie występuje, szpital zaś jest określony jako „zakład użyteczności publicznej, przeznaczony do leczenia chorych obłożnych", czyli ciężko chorych ${ }^{2}$. Czy wobec tego profil działań lecznicy wykluczał chorych przewlekle? Niekoniecznie, podaje się bowiem przykłady lecznic chorób płuc, chorób układu krążenia czy chorób psychicznych ${ }^{3}$, a w tych zakresach proces leczenia przebiegał w trybie wielomiesięcznym lub wieloletnim ${ }^{4}$. Kluczowa jest tu kwestia własności danej placówki i jej organizacji. Właściciel niepubliczny, o ile nie

\footnotetext{
1 Wielka Ilustrowana Encyklopedia Powszechna Wydawnictwa Gutenberga, t. IX (Kraków: Wydawnictwo Gutenberga, [1929-1931]), 19.

2 Trzaski, Everta i Michalskiego leksykon: encyklopedja powszechna ilustrowana w 1 tomie A-Z, red. Stanisław Lam (Warszawa: Trzaska, Evert, Michalski, 1936/1937), kolumna 2234, 1501.

3 Wielka Ilustrowana Encyklopedia Powszechna, 19.

4 W gdyńskim Szpitalu Sióstr Miłosierdzia średni czas pobytu pacjenta w 1929 r. wynosił 21 dni, przy czym placówka leczyła głównie przypadki chorób wewnętrznych (37\%) i chirurgiczne (34\%) oraz grypę (7\%). Zob. Sprawozdanie roczne o ruchu chorych ze Szpitala Sióstr Miłosierdzia w Gdyni za rok 1929, [1930], Archiwum Państwowe w Bydgoszczy (dalej cyt. APB), zespół Pomorski Urząd Wojewódzki w Toruniu (dalej cyt. PUW), sygn. 4/11591, brak paginacji.
} 
było nim zgromadzenie zakonne powołane do służby przy chorym bądź stowarzyszenie charytatywne, mógł prowadzić profil działalności ukierunkowany na choroby przewlekłe, mając jedynie stałą grupę pacjentów prywatnych lub ubezpieczonych przynoszących mu dochód. Inaczej nie byłby w stanie pokryć wydatków. Owszem, pacjenci ubezpieczeni, tak w ramach międzywojennych Kas Chorych, jak i przez późniejszą Ubezpieczalnię Społeczną ${ }^{5}$ mogli podjąć leczenie w klinice prywatnej, musiał być z nią jednak podpisany rodzaj kontraktu na leczenie (w niektórych przypadkach pacjenci mogli występować o zwrot nakładów). Praktyka pokazywała zatem, że dla inwestora prywatnego bezpieczniejszym rozwiązaniem było tworzenie placówek o węższej specjalizacji i to w zakresie lecznictwa krótkoterminowego, czyli wykonywania drobnych zabiegów czy leczenia ambulatoryjnego. Należało tu wyczuć koniunkturę i zapełnić określoną niszę, tak aby powoływana firma miała podstawy do utrzymania się na rynku.

Celem niniejszego artykułu nie jest przedstawienie całokształtu zagadnień gdyńskiego szpitalnictwa, a jedynie studium przypadku jednej z placówek - Lecznicy Nadmorskiej w Gdyni. Zainteresowanie nią wyrażali niegdyś zgłębiający dzieje gdyńskiej medycyny lekarze, którzy, nie unikając przy tym błędów warsztatowych, przybliżyli zainteresowanym jej ciekawe losy ${ }^{6}$. Niestety, mimo upływu lat i postępu badań niektóre mylne tezy, jak tę o rzekomym funkcjonowaniu w latach 1925-1938, nadal się powiela ${ }^{7}$. Realizacja zaproponowanego tematu ma pomóc w ostatecznym wyjaśnieniu pewnych wątków, ale przede wszystkim - osadzić historię Lecznicy w szerszym kontekście. Stąd wskazane jest między innymi choćby skrótowe nakreślenie miejscowej sytuacji lecznictwa zamkniętego na przełomie lat dwudziestych i trzydziestych XX w. W pierwszym półroczu 1927 r. w budynku o funkcjach letniskowych gdyńskie zgromadzenie Sióstr Miłosierdzia św. Wincentego à Paulo uruchomiło pierwsze ambulatorium. Od 1928 r. rozwinięto jego formułę do szpitalnej, wykorzystując przyległy nowo powstały obiekt, który nie był jednak projektowany jako lecznica. Rok później staraniem władz samorządowych działalność zainaugurował Miejski Szpital Zakaźny, zlokalizowany w części budynku po dawnym folwarku państwowym na Grabówku. Tym samym oba obiekty w Gdyni wykorzystywane na cele lecznictwa zamkniętego zostały wtórnie przystosowane do wskazanej funkcji ${ }^{8}$.

5 Kasy Chorych powołano 11 stycznia 1919 r., a zlikwidowano je, przekształcając w Ubezpieczalnię Społeczną, na podstawie przepisów z 24 października 1934 r. Zob. Encyklopedia Historii Drugiej Rzeczypospolitej (Warszawa: Wiedza Powszechna, 1999), 149-150. Należy dodać, że na obszarze byłego zaboru pruskiego istniały zorganizowane struktury kas chorych i tradycje tej formy systemu lecznictwa ubezpieczeniowego.

6 Eugeniusz Biadała, „Pierwszy szpital”, Rocznik Gdyński 8, 1987/88 (1989); Andrzej Kolejewski, „Lecznica Nadmorska”, w Encyklopedia Gdyni (Gdynia: Oficyna Verbi Causa, 2006), 396.

7 Paweł Różyński, „Lecznica Nadmorska - pierwszy szpital w Gdyni”, City News, www.gdynia-moje-miasto.pl/lecznica-nadmorska-pierwszy-szpital-w-gdyni, dostęp: 11 XI 2019.

\& Marcin Szerle, „Gdynia na drodze ku nowoczesności. Medyczne i sanitarne aspekty życia w mieście portowym”, w Czystość i brud. Higiena między wielkimi wojnami (1918-1939), 


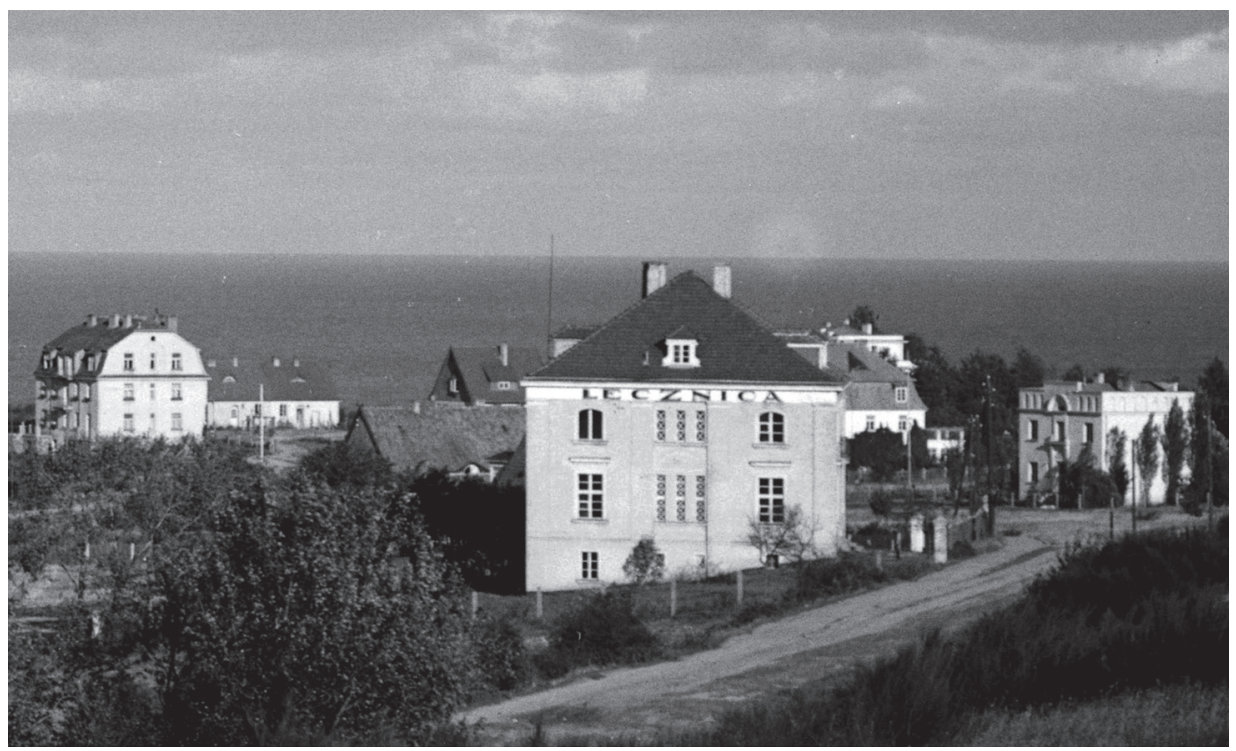

Il. 1. Lecznica Nadmorska, 1929-1932, fot. autor nieznany, zbiory Muzeum Miasta Gdyni

Dopiero Szpital Morski Marynarki Wojennej (projekt 1930, realizacja 1932 r.) przyniósł w tym zakresie daleko idącą zmianę 9 .

Powodów, dla których nie powstał w Gdyni w latach dwudziestych budynek o pierwotnie szpitalnym przeznaczeniu, było przynajmniej kilka. Mieszkańcy wsi i okolic byli dotąd otoczeni opieką placówek wejherowskich, a także gdańskich, od 1920 r. znajdujących się de facto za granicą, choć w podobnie niewielkiej odległości. Decyzja o budowie portu przyniosła nagłe i - w krótkiej perspektywie - daleko idące zmiany zarówno dla Gdyni, jak i całego regionu. Napływ ludności, przenosiny i organizacja urzędów państwowych oraz Marynarki Wojennej zachwiały dotychczasowymi strukturami: społeczną, gospodarczą, ekonomiczną, odegrały przy tym kluczową rolę w przekształcaniu się wsi w miasto. Elementem zmian było zaburzenie równowagi - stosując dzisiejsze nazewnictwo - gospodarki nieruchomościami. Zapotrzebowanie na pomieszczenia dla urzędów, lokale mieszkalne i użytkowe było tak duże, że podmioty prywatne, samorządowe i rządowe nie nadążały z inwestycjami. Z drugiej zaś strony, zaskoczone skalą przeobrażeń samorządy, wiejski, a później miejski, nie były w stanie skonstruować budżetów obejmujących znacznie rozszerzony zakres działań. Rozwój organizacji ochrony zdrowia w Gdyni nie był również finansowym priorytetem władz centralnych, mających

red. Walentyna Korpalska, Wojciech Ślusarczyk (Bydgoszcz: Uniwersytet Mikołaja Kopernika w Toruniu, 2017), 357-358.

9 Bliżej o tej placówce zob. artykuł Weroniki Szerle Między klasyką a awangardą. Szpital Morski na Oksywiu projektu Mariana Lalewicza w niniejszym tomie. 
przed sobą wiele wyzwań infrastrukturalnych, odpowiadających na potrzeby portu, Marynarki Wojennej i floty. Kasę Chorych, jeszcze z siedzibą w Wejherowie, stać było jedynie na dofinansowanie mniejszych inicjatyw ${ }^{10}$.

W kluczowym dla tematu 1929 r. pierwsza i główna placówka lecznicza w Gdyni - wspomniany Szpital Sióstr Miłosierdzia - rozszerzyła się o 15 łóżek, dochodząc do liczby 40 na oddziałach internistycznym, okulistycznym i pediatrycznym. Jedynie sześć miejsc przeznaczono dla pacjentów wymagających interwencji chirurgicznych. Zachowane dane nie wyszczególniają porodów i schorzeń ginekologicznych ${ }^{11}$. Ze statystyk wiemy, że w 1929 r. w Gdyni miały miejsce 474 urodzenia, ponad dwukrotnie więcej niż rok wcześniej i blisko trzy i pół raza więcej w stosunku do $1927 \mathrm{r}^{12}$ Należy przyjąć, że niewielka część porodów miała miejsce w szpitalu, pozostałe zaś przyjęly praktykujące na terenie Gdyni i okalających ją wsi (późniejszych dzielnic) akuszerki, których było przynajmniej osiem ${ }^{13}$. Taki obraz sytuacji dawał podstawy do biznesowego myślenia o położnictwie. Próbę, nieudaną, założenia prywatnej kliniki położniczej przeprowadziła akuszerka Karolina Czechowa. W jej argumentacji pojawiają się wątki odmów szpitala kongregacyjnego przyjmowania rodzących oraz niemożność obsługi wszystkich chętnych w Wejherowie. Zaniepokojone sytuacją starostwo wskazywało na konieczność założenia u sióstr oddziału patologii ciąży ${ }^{14}$. To jednak nie nastąpiło.

Odnosząc się do 1929 r., wskazać również należy, że doszło wówczas do 91 wypadków w porcie wymagających interwencji gdyńskiego pogotowia ratunkowego ${ }^{15}$. Tym zaś prawdopodobnie kierował już wtedy, Miron Mikiciński ${ }^{16}$. Nowo przybyły, bo w 1929 r., do Gdyni lekarz specjalista chirurg (ur. w 1889 r., w 1911 r. ukończył

10 Przykładem może być tu zgoda na uzupełnienie wyposażenia Szpitala Sióstr Miłosierdzia. Zob. Pismo Okręgowego Urzędu Ubezpieczeń w Poznaniu do Komisarza Powiatu Morskiego w Wejherowie, 26 września 1928 r., APB, PUW, sygn. 4/11786, brak paginacji.

11 Szpitalnictwo w Gdyni. Referat, 1930 r., Archiwum Państwowe w Gdańsku Oddział w Gdyni (dalej cyt. APGoG), zespół Komisariat Rządu w Gdyni (dalej cyt. KRz), sygn. 682/577, s. 1; Spis szpitali i zakładów leczniczych istniejących na obszarze powiatu gdyńskiego w końcu 1929 roku, [1930 r.], APB, PUW, sygn. 4/11827, brak paginacji; Sprawozdanie roczne o ruchu chorych ze Szpitala Sióstr Miłosierdzia w Gdyni za rok 1929, [1930], APB, PUW, sygn. 4/11591, brak paginacji.

12 Rocznik Statystyczny Gdyni 1933-1934, red. Bolesław Polkowski (Gdynia: Komisariat Rządu w Gdyni, 1934), 12.

13 Marcin Szerle, „Kobiety w gdyńskich strukturach medycznych okresu międzywojennego”, Rocznik Gdański, t. LXXIII-LXXIV, 2013-2014 (2016): 110.

14 Marcin Szerle, „Cienie i blaski służby bociana - opieka akuszeryjna w Gdyni w latach 1920-1939”, w Wędrówki po dziejach Gdyni, cz. III, red. Dagmara Płaza-Opacka, Tadeusz Stegner (Gdynia: Muzeum Miasta Gdyni, 2015), 96. Wiarygodność Czechowej poddawana była przez ówczesnych w wątpliwość, możliwe przy tym, że władze prowadzącego placówkę zgromadzenia odmawiały przyjęcia ciężarnych niezamężnych lub spoza Kościoła katolickiego.

15 Rocznik Statystyczny, 20.

16 Marcin Szerle, „Na styku miasta i portu - organizacja i funkcjonowanie służb ratowniczych w międzywojennej Gdyni”, w Zawód ratownika medycznego na ziemiach polskich w XIX i XX wieku, red. Bożena Urbanek (Warszawa: Oficyna Wydawnicza ASPRA-JR, 2012), 220-221. Przedwojennym 
studia w Monachium). Jego kolegą i późniejszym wspólnikiem był Stanisław Bobkowski, lekarz ogólny (ur. w 1889 r., absolwent uczelni berlińskiej w 1913 r.) ${ }^{17}$. Wszystko wskazuje, że obaj bardzo szybko rozpoznali sytuację zdrowotną Gdyni, dostrzegając największe potrzeby w zakresie lecznictwa. Najpewniej sami zainicjowali rozmowy z władzami samorządowymi, zmierzające do powołania „lecznicy chirurgiczno-ginekologiczno-akuszeryjnej" - prywatnej, ale dofinansowanej przez miasto. Rangę sprawy potwierdza zaangażowanie władz wojewódzkich i, z ich polecenia, gdyńskiego lekarza powiatowego ${ }^{18}$. Do porozumienia udało się dojść jeszcze przed końcem roku, a nowy dyrektor - Mikiciński - objął placówkę z 36 łóżkami (20 przypadło chirurgii, osiem położnictwu, sześć ginekologii i dwa innym przypadkom $)^{19}$. Lecznicę zorganizowano w prywatnej willi w obrębie Kamiennej Góry (dziś ul. Partyzantów 24), którą przystosowano - w miarę możliwości technicznych - do funkcji szpitalnych. Jej otwarcie nastąpiło około 20 listopada 1929 r. ${ }^{20}$ Zgodnie z ówczesną praktyką korzystać można było z warunków ujętych w trzy klasy jakościowe. Szczegółów nie znamy, jednak mogło chodzić o pokoje jedno- lub wieloosobowe, dodatkowe wyposażenie lub ewentualnie o wyżywienie. Pacjenci wykupujący I lub II klasę osobno nabywali też materiały lub usługi, źródła nie określają jednak, o jakich mowa. W połowie $1930 \mathrm{r}$. miejsc dla klas I, II i III było odpowiednio siedem, osiem i $20^{21}$. Jeszcze $\mathrm{w}$ tym samym roku zrezygnowano z I klasy oraz z pobierania dodatkowych opłat ${ }^{22}$.

W zakresie lecznictwa statystyki dla 1929 r. mówią o 138 pacjentach, spośród których najwięcej wymagało opieki chirurgicznej (58\%), ginekologicznej (14\%), internistycznej (13\%), położniczej (8\%). Sprawowało ją trzech lekarzy i tyleż pielęgniarek przy ośmiu osobach personelu gospodarczego ${ }^{23}$. W prasie

lekarzem pogotowia był również Stanisław Bobkowski, przy czym trudno jest wskazać dokładny okres jego zatrudnienia.

17 Kronika Domu Sióstr Miłosierdzia Św. Wincentego à Paulo w Gdyni, Zgromadzenie Sióstr Miłosierdzia Św. Wincentego à Paulo w Gdyni, s. 8; [Wykaz lekarzy z terenu miasta Gdyni uprawnionych do praktyki lekarskiej według stanu z 30.VI.br.], 1933 r., APB, PUW, sygn. 4/11647, brak paginacji.

18 Sprawozdanie A[ndrzeja] Krysińskiego z wizyty do Kartuz i Gdyni, 10-12.10.1929 r., 1929 r., APB, PUW, sygn. 4/11478, brak paginacji.

19 Spis szpitali i zakładów leczniczych istniejących na obszarze Powiatu Gdyńskiego w końcu 1929 roku, [1930 r.], APB, PUW, sygn. 4/11827, brak paginacji.

20 Dziennik Gdyński 271, 26 XI 1929 r., 2.

${ }^{21}$ Sprawozdanie roczne o ruchu chorych w Lecznicy Nadmorskiej, Zakładu chirurgicznego, ginekologicznego i położniczego w Gdyni, Kamienna Góra, [1930 r.], APB, PUW, sygn. 4/11591, brak paginacji. Różnica w klasach w 1929 r. była znaczna: III - 8 zł, II - 15 zł, I - ustalana indywidualnie. Porównawczo w Szpitalu Sióstr Miłosierdzia taksa wynosiła: III - 7 zł, II - 12 zł, III - 18 zł. Patrz: Sprawozdanie roczne o ruchu chorych ze Szpitala Świętego Wincentego w Gdyni w 1930 roku, [1931 r.], APB, PUW, sygn. 4/11597, brak paginacji.

22 Sprawozdanie roczne o ruchu chorych z Lecznicy Nadmorskiej w Gdyni za rok 1930, [1931 r.], APB, PUW, sygn. 4/11597, brak paginacji. Ówczesne stawki według klas: III - 7 zł, II - 12 zł.

${ }_{23}$ Sprawozdanie roczne o ruchu chorych w Lecznicy Nadmorskiej, Zakładu chirurgicznego, ginekologicznego i położniczego w Gdyni, Kamienna Góra, [1930 r.], APB, PUW, sygn. 4/11591, brak paginacji. 


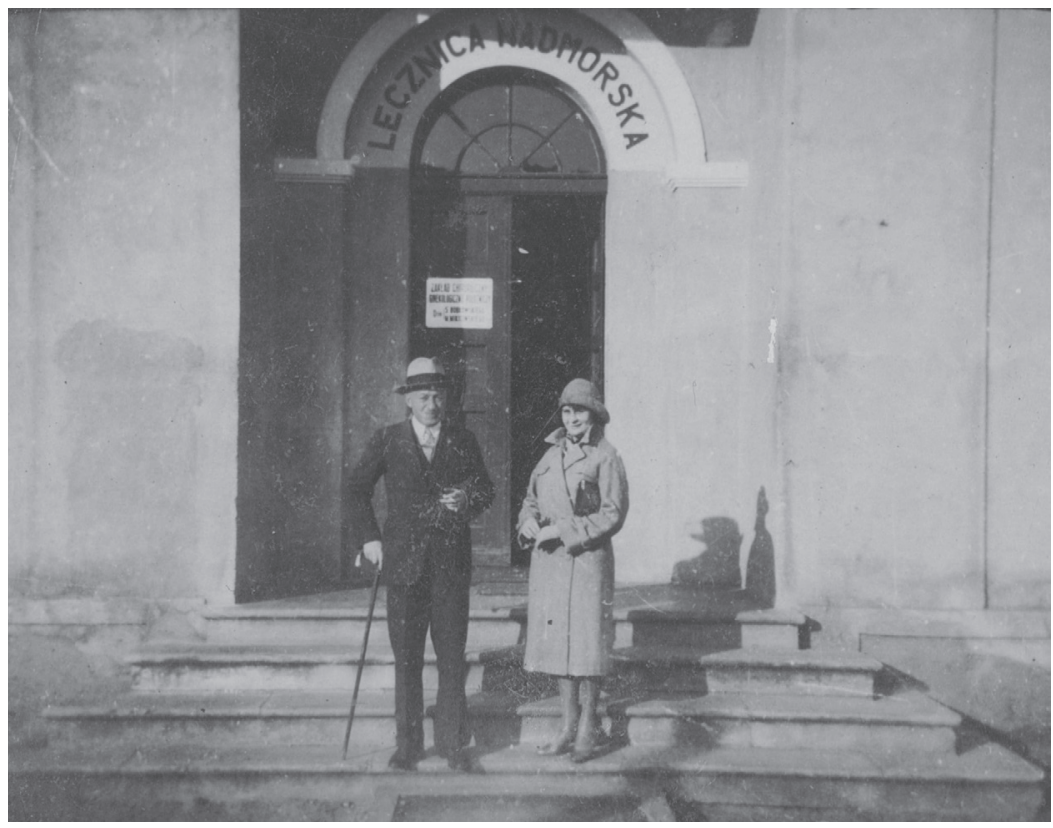

Il. 2. Wejście do Lecznicy Nadmorskiej, 1930-1931, po lewej prawdopodobnie Miron Mikiciński, fot. Zbigniew Tustanowski, własność prywatna

znalazło się nawet ogłoszenie o treści „Dobra kucharka potrzebna od zaraz do Lecznicy Nadmorskiej" ${ }^{24}$. Średni czas pobytu pacjenta wyniósł dziewięć dni25. Według reklamy prasowej był to „Zakład chirurgiczny i ginekologiczno-położniczy wyposażony według najnowszej techniki lekarskiej z salą operacyjną, porodową, opatrunkową, laboratorium analitycznem i rentgenem"26. W 1930 r. personel w składzie: czterech lekarzy, sześć pielęgniarek i pięć osób pomocniczych obsłużył 975 pacjentów, w tym 129 położniczych, 833 pozostałych i 12 onkologicznych, ci ostatni średnio spędzili w szpitalu po 13 dni. Szczegółową ocenę utrudniają tu połączone dane dla chirurgii, ginekologii, okulistyki i laryngologii ${ }^{27}$. Stan placówki na koniec 1930 r. to 36 łóżek (26 chirurgicznych i 10 położniczych) ${ }^{28}$.

24 Ogłoszenie, Dziennik Gdyński 202, 2 września 1930 r., s.4.

25 Sprawozdanie roczne o ruchu chorych w Lecznicy Nadmorskiej, Zakładu chirurgicznego, ginekologicznego i położniczego w Gdyni, Kamienna Góra, [1930 r.], APB, PUW, sygn. 4/11591, brak paginacji.

26 Paweł Różyński, „Lecznica Nadmorska - pierwszy szpital w Gdyni”, City News, www.gdynia-moje-miasto.pl/lecznica-nadmorska-pierwszy-szpital-w-gdyni/, dostęp: 11 XI 2019.

27 Sprawozdanie roczne o ruchu chorych z Lecznicy Nadmorskiej w Gdyni za rok 1930, [1931 r.], APB, PUW, sygn. 4/11597, brak paginacji.

28 Spis szpitali i zakładów leczniczych istniejących na obszarze Województwa Pomorskiego w końcu 1930 roku, [1931 r.], APB, PUW, sygn. 4/11687, brak paginacji. 
W 1931 r. zatrudniano po troje lekarzy i pielęgniarek, którym pomagało dziewięć osób na niższych stanowiskach. Wzrosła liczba pacjentów - do 1299 - na co mogło wpłynąć zwiększenie zakresu opieki o inne jednostki chorobowe. Pacjentek ginekologicznych i położniczych było tu 480, a przypadków chirurgicznych $761^{29}$.

Czy Lecznica Nadmorska miała silną konkurencję ze strony innych gdyńskich placówek? Sprawozdania ze Szpitala Sióstr Miłosierdzia oraz z Miejskiego Szpitala Zakaźnego na to nie wskazują. Na oddziale chirurgicznym u Sióstr w 1930 r. leczono 188 osób ( $23 \%$ wszystkich pacjentów), ale tendencja była zniżkowa ${ }^{30}$. Rok później przyjęto 268 pacjentów chirurgicznych (20\%), a także dwa przypadki komplikacji położniczych $^{31}$. W $1930 \mathrm{r}$. w szpitalu zakaźnym ratowano jedną kobietę z posocznicą połogową ${ }^{32}$, jednak nie wydaje się, aby przy tak poważnym zakażeniu bakteryjnym mogła trafić do mocno obłożonej Lecznicy, w dodatku pozbawionej odpowiedniej izolatki. Lekarze placówki leczyli również dwie przypadłości położnicze w roku następnym ${ }^{33}$. Dane wskazują, że w wypadku schorzeń ginekologicznych, patologii ciąży, porodów oraz problemów okresu połogowego Lecznica przejęła praktycznie całość „rynku” lecznictwa zamkniętego (większość porodów przyjmowały akuszerki). W odniesieniu do interwencji chirurgicznych placówka zdobyła natomiast znaczną część pacjentów z Gdyni i okolic w 1930 r., by rok później obsłużyć blisko trzy razy tylu chorych, co szpital Sióstr ${ }^{34}$. Tym samym duet przedsiębiorczych lekarzy osiągnął przynajmniej część zamierzeń. Pozycja Lecznicy wydawała się stabilna, zapewniając jeśli nie duży dochód, to przynajmniej pokrycie wydatków.

Gwarancją tego miało być wsparcie ze strony samorządu. W 1930 r. miesięczna subwencja dla placówki wynosiła 2500 zł (założono roczną kwotę 30000 zł), a w jej ramach miasto zyskiwało do dyspozycji łóżka II i III klasy - możliwość obsługi mieszkańców, którzy potrzebowali specjalistycznej pomocy ${ }^{35}$. Na lata budżetowe 1930/1931 oraz 1931/1932 przyjęto kwotę w tej samej wysokości ${ }^{36}$. Wiemy, że od każdego pacjenta ubezpieczonego w Kasie Chorych Gdynia płaciła dodatkowo 2 zł za dzień ${ }^{37}$. Lecznica miała przychylność, a czasem dodatkowe wsparcie

29 Sprawozdanie roczne o ruchu chorych z Lecznicy Nadmorskiej w Gdyni za rok 1931, [1932 r.], APB, PUW, sygn. 4/11600, brak paginacji.

30 Sprawozdanie roczne o ruchu chorych ze Szpitala Świętego Wincentego w Gdyni w 1930 roku, [1931 r.], APB, PUW, sygn. 4/11597, brak paginacji.

31 Sprawozdanie o ruchu chorych ze Szpitala Sióstr Miłosierdzia Św. Wincentego a Paulo za 1931 rok, [1932 r.], APB, PUW, sygn. 4/11600, brak paginacji.

32 Sprawozdanie roczne o ruchu chorych ze Szpitala Miejskiego Zakaźnego za rok 1930, [1931 r.], APB, PUW, sygn. 4/11597, brak paginacji.

33 Sprawozdanie roczne o ruchu chorych ze Szpitala dla zakaźnych w Gdyni za 1931 rok, [1932 r.], APB, PUW, sygn. 4/11597, brak paginacji.

34 Sprawozdanie roczne o ruchu chorych z Lecznicy Nadmorskiej w Gdyni za rok 1931, [1932 r.], APB, PUW, sygn. 4/11600, brak paginacji.

35 Ogólne dane o mieście portowem Gdyni, [1930 r.], APB, PUW, sygn. 4/9024, brak paginacji.

36 Budżet Sanitarny Miasta Gdyni, [1930 r.], APB, PUW, sygn. 4/11480, brak paginacji.

37 „Rada Miejska przy pracy”, Dziennik Gdyński 249, 28 października 1932 r., 4. 
Kasy Chorych, której lekarzem naczelnym, przynajmniej w 1930 r., był... Stanisław Bobkowski ${ }^{38}$. Nie uszło to uwadze ówczesnych i budziło kontrowersje. W dokumencie powstałym po kontroli odbytej na przełomie lutego i marca 1931 r. czytamy następującą opinię - „Wysoce niewłaściwy i szkodliwy dla Kasy fakt, iż. Nacz. lekarz jest jednocześnie właścicielem lecznicy Nadmorskiej - decyduje o wysłaniu chorych kasowych do lecznicy i zgłasza do Kasy zapotrzebowanie na środki lecznicze, nad którymi brak ewidencji i kontroli” ${ }^{39}$. Dalszy ciąg sprawy nie jest znany. O tym, jak ważne były kontakty, w listach do żony pisał ginekolog Jerzy Krzyżanowski (ur. w 1898 r., dyplom we Lwowie w 1924 r.) $)^{40}$. Cieszył się z mianowania, przy Bobkowskim, na kuratora Lecznicy. Nastawiał się przy tym, że w razie nieprawidłowości w placówce utrze jej współwłaścicielowi nosa. Tak się jednak nie stało, według opinii syna Krzyżanowskiego, jego ojciec i Bobkowski szybko się zaprzyjaźnili, a połączył ich wspólny cel - zdobycie przychylności Kasy Chorych. Bez jej dofinansowania trudno było bowiem utrzymać prywatną praktykę. Po siedmiu miesiącach kuluarowych zabiegów Krzyżanowskiemu powierzono prowadzenie Stacji Opieki nad Matką Ciężarną i w podziękowaniu skierował do Bobkowskiego pierwszy poród. Po kilku dniach, jeszcze w grudniu 1930 r., otrzymał informację, że został nominowany na kierownika ambulatorium. Relacjonował wówczas żonie: „Uważam, że z tutejszymi ludźmi da się wiele załatwić przy kieliszku. Z okazji zjazdu lekarzy powiatowych, gdzie byli i Bobkowski i Gaszkowski, Związek wyraził zgodę na ambulatorium, a Bobkowski, przyjaciel od serca, przyrzekł już tę sprawę załatwić. W ogóle przyjaźń wielka"41.

Mikiciński i Bobkowski - wspólnicy „Lecznicy Nadmorskiej. Zakładu chirurgicznego, ginekologiczno-położniczego" - szybko stali się osobistościami w lokalnym środowisku lekarskim. Pamiętajmy, że konkurowało ono o pacjentów i wpływy, choć potrafiło przy tym jednoczyć siły i się solidaryzować. Dzięki prasie znane jest stanowisko 17 gdyńskich lekarzy wobec zarzutów „Expressu Ilustrowanego" z 11 października 1931 r. Nie podano szczegółów, ale dwóm lekarzom - najpewniej Bobkowskiemu i Mikicińskiemu, gdyż nie są sygnatariuszami dokumentu - wytknięto nieetyczne zachowanie w obliczu katastrofalnego wybuchu gazu w budynku mieszkalnym przy ul. Bema. Z opublikowanego listu

38 Spis lekarzy i lekarzy-dentystów zamieszkałych w Gdyni na dzień 30 czerwca 1930 r., APB, PUW, sygn. 4/11645, brak paginacji. Kasa Chorych dopłacała do leczenia mieszkańców gminy - w 1930 r. była to kwota 2000 zł. Patrz: Budżet Sanitarny Miasta Gdyni, [1930 r.], APB, PUW, sygn. 4/11480, brak paginacji.

39 Okręgowy Urząd Ubezpieczeń w Poznaniu, Wyciąg ze sprawozdania Biura Komisarzy Rewizyjnych z dnia 31 lipca 1931 r., Archiwum Państwowe w Poznaniu, zespół Okręgowy Urząd Ubezpieczeń w Poznaniu, sygn. 791/102, brak paginacji.

40 [Wykaz lekarzy z terenu miasta Gdyni uprawnionych do praktyki lekarskiej według stanu z 30 czerwca br.], 1933 r., APB, PUW, sygn. 4/11647, brak paginacji.

${ }^{41}$ Jerzy Krzyżanowski, Magda Krzyżanowska-Mierzewska, Według ojca, według córki. Historia rodu (Warszawa: W.A.B., 2010), 111, 116. 


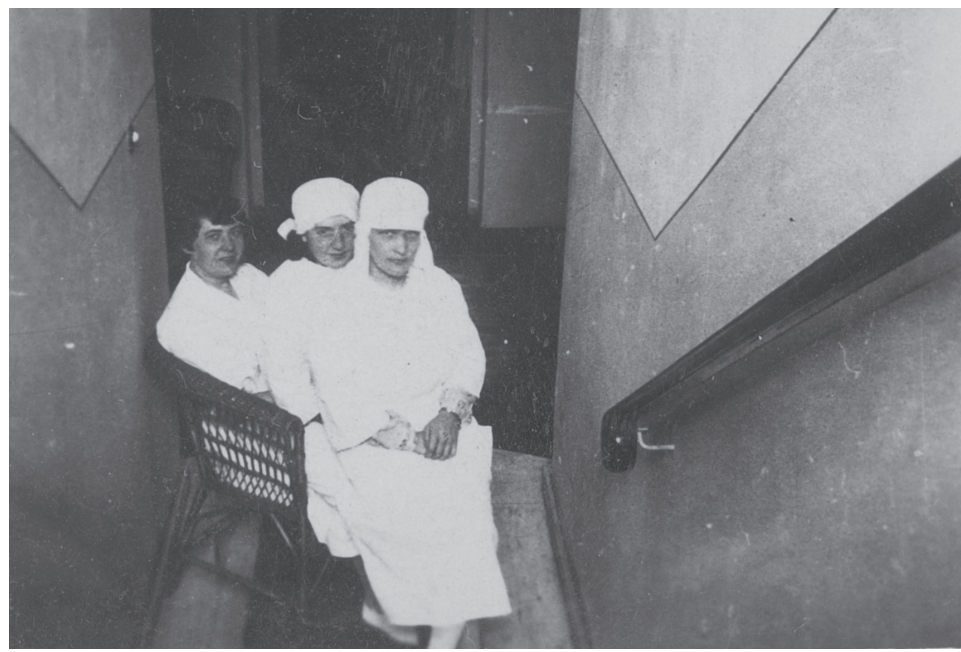

Il. 3. Personel placówki, 1930-1931, fot. Zbigniew Tustanowski, własność prywatna

dowiadujemy się, że Bobkowski skierował na miejsce pogotowie ratunkowe oraz lekarzy Kasy Chorych, a Mikiciński zadbał o gotowość Lecznicy Nadmorskiej i dyżurującego tam Aleksandra Fomickiego ${ }^{42}$. Przy okazji tej sprawy poznaliśmy nazwisko tego zatrudnionego w placówce lekarza, o którym brak jednak bliższych informacji. Kolejnym pracownikiem był Feliks Pokutyński, internista (ur. w 1904 r., absolwent uczelni w Poznaniu w 1930 r.), w 1932 r. będący asystentem w Lecznicy ${ }^{43}$. Z kolei Kazimierz Bielawski, lekarz ogólny (ur. w 1893 r., w 1926 r. ukończył studia w Poznaniu ${ }^{44}$, udzielał pomocy trzem uczestnikom nocnej strzelaniny odwiezionym do Lecznicy ${ }^{45}$. To dowód na zgodność dyspozycyjności personelu z reklamą prasową, głoszącą „przyjmowanie chorych odbywa się w ciągu całej doby" ${ }^{46}$. Kolejnym lekarzem figurującym w dokumentach jako pracownik zakładu był Zbigniew Kazimierz Tustanowski (ur. w 1904 r., dyplom we Lwowie w 1930 r.), dopisany wtórnie do wykazu lekarzy z 30 czerwca 1930 r. ${ }^{47}$ Brak szczegółowych danych na temat innych osób zatrudnionych w Lecznicy.

42 C. Rogala i inni, „Protest lekarzy gdyńskich”, Dziennik Gdyński 239, 16 października 1931 r., s. 3.

${ }^{43}$ Wykaz lekarzy urzędowych zatrudnionych w I i II instancji administracji ogólnej względnie pozostałych na służbie państwowej, 1932 r., APB, PUW, sygn. 4/11647, brak paginacji. Pokutyński jest odręcznie wykreślony piórem, co może wskazywać, że przenosiny do Lecznicy skutkowały zwolnieniem $\mathrm{z}$ dotychczasowego miejsca pracy.

44 [Wykaz lekarzy $\mathrm{z}$ terenu miasta Gdyni uprawnionych do praktyki lekarskiej według stanu z 30 czerwca br.], 1933 r., APB, PUW, sygn. 4/11647, brak paginacji.

45 „Ostre starcie na tle mieszkaniowem”, Dziennik Gdyński 223, 27 października 1931 r., s. 3.

46 Paweł Różyński, „Lecznica Nadmorska - pierwszy szpital w Gdyni”, City News, www.gdynia-moje-miasto.pl/lecznica-nadmorska-pierwszy-szpital-w-gdyni/, dostęp: 11 XI 2019.

47 Wykaz lekarzy Województwa Pomorskiego według stanu na dzień 30 czerwca 1930 r., APB, PUW, sygn. 4/11645, brak paginacji. Ostatni dopisek na liście pochodzi z 31 grudnia $1931 \mathrm{r}$. 
Pomimo wymienionych wcześniej sprzyjających okoliczności rynkowych i politycznych (w wymiarze lokalnym) po około trzech latach Lecznica przestała istnieć. Problemem, który uniemożliwił dalsze prowadzenie przedsiębiorstwa, były niewystarczające finanse, choć nie można wykluczyć, że sprawa miała głębsze, branżowe podłoże. Co prawda, opinia inspekcji z Torunia była pozytywna: dostateczne - czystość i porządek, dobre - opieka lekarska i pomoc, smaczne jedzenie, niepokój wzbudziła jedynie ciasnota ${ }^{48}$, ale już dwa lata później to się zmieniło. W opinii lekarza powiatowego, internisty Józefa Stankiewicza (ur. w 1900 r., absolwent uczelni lwowskiej w 1926 r. $)^{49}$, placówkę prowadzono niedbale, była miejscem wyzysku chorego, a społeczność lokalna silnie ją krytykowała. Miała nie tylko nie zostawiać po sobie dobrego wrażenia, co wręcz zepsuć opinię o lekarzach. Tak surowa ocena, wyrażana w piśmie służbowym kierowanym do władz wojewódzkich, dziwi. Tym bardziej że Stankiewicz sam podpisał się pod wspomnianym listem broniącym postawy lekarzy po wybuchu gazu. Być może Bobkowski i Mikiciński zbyt stanowczo wyrażali swoje oczekiwania wobec miasta. Mieli zażądać pięcioletniego kontraktu, płatnego z góry na dwa lub trzy lata (ok. $100000 \mathrm{zł}$ ), podniesienia rocznej subwencji do około $50000 \mathrm{zł}$, zapowiadając zamknięcie firmy w razie odmowy. Samorząd, a na pewno Stankiewicz, zdawał sobie sprawę, że inwestowanie znaczących kwot w klinikę prywatną (również na przebudowę niefunkcjonalnych wnętrz) oddala budowę szpitala miejskiego z prawdziwego zdarzenia. A na tym chciano się koncentrować. Ostatecznie strony nie doszły do porozumienia, a po negocjacjach miasto wykupiło wyposażenie Lecznicy za $20000 \mathrm{zł}$, przy pierwotnie proponowanej przez właścicieli kwocie 70000 zł. Mieli oni dodatkowo przez 2,5 roku otrzymywać 10000 zł rocznej dzierżawy ${ }^{50} .1$ października 1932 r. placówka została zamknięta ${ }^{51}$.

Kupiony sprzęt miał zostać przekazany do Szpitala Sióstr, gdzie planowano otworzyć oddział położniczy. Z kolei willę na Kamiennej Górze chciano tymczasowo przeznaczyć na siedzibą Miejskiego Szpitala Zakaźnego ${ }^{52}$. O ile wyposażenie podzielono i do Sióstr trafiło 20 łóżek położniczych, meble, w tym szafki nocne, specjalistyczne narzędzia oraz bielizna, o tyle przeprowadzka nie doszła do skutku ${ }^{53}$. Mimo kon-

Zatrudnienie nastąpiło w I kwartale 1931 r. Patrz: załącznik do pisma Izby Lekarskiej Poznańsko-Pomorskiej do PUW, 10 października 1931 r., APB, PUW, sygn. 4/11551, brak paginacji.

48 [Sprawozdanie dra Krysińskiego z podróży inspekcyjnej, odbytej w dniach 3-6 kwietnia 1930 r.], APB, PUW, sygn. 4/12048, brak paginacji.

49 [Wykaz lekarzy z terenu miasta Gdyni uprawnionych do praktyki lekarskiej według stanu z 30.VI.br.], 1933 r., APB, PUW, sygn. 4/11647, brak paginacji.

50 Pismo Józefa Stankiewicza do Naczelnika Wydziału Zdrowia PUW, 20 października 1932 r., APB, PUW, sygn. 4/11692, brak paginacji.

51 Pismo lekarza powiatowego do PUW, 31 października 1933 r., APB, PUW, sygn. 4/11740, brak paginacji.

${ }_{52}$ „Rada Miejska przy pracy”, Dziennik Gdyński 249, 28 października 1932 r., s. 4.

53 Pismo Józefa Stankiewicza do Naczelnika Wydziału Zdrowia PUW, 20 października 1932 r., APB, PUW, sygn. 4/11692, brak paginacji; Sprawozdanie półroczne z czynności Lekarza Powiatowego dr J. Stankiewicza za II półrocze 1932 r., [1933 r.], APB, PUW, sygn. 4/11601, brak paginacji. 


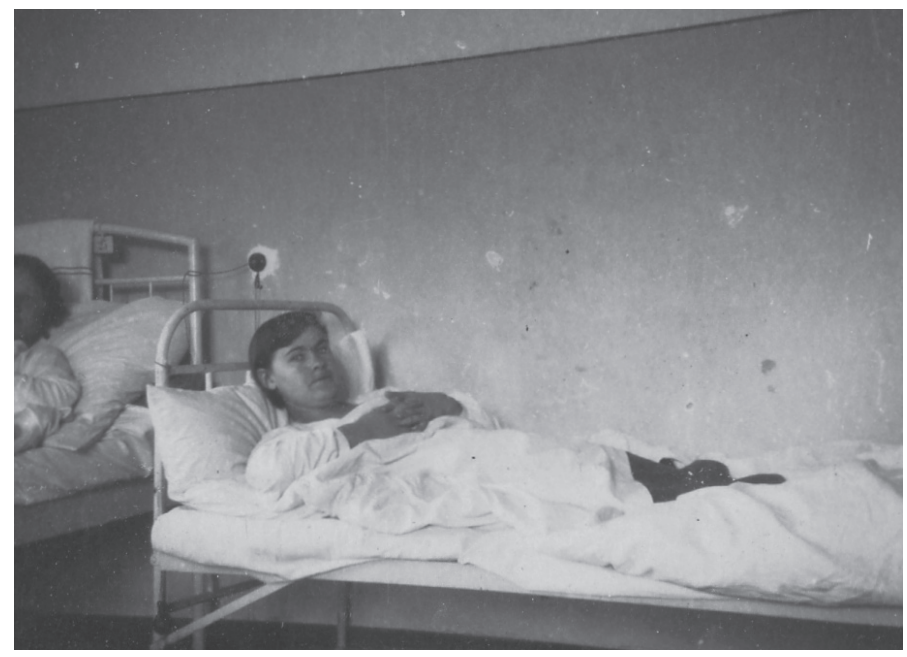

Il. 4. Pacjentki na oddziale, 1930-1931, fot. Zbigniew Tustanowski, własność prywatna

kretnego planu działania zadecydowały o tym względy finansowe oraz zdecydowane protesty mieszkańców pobliskich budynków, obawiających się, że sąsiedztwo szpitala zakaźnego odstraszy turystów ${ }^{54}$. Dopiero 29 kwietnia 1934 r. w nowym budynku Sióstr Miłosierdzia uruchomiono oddział ginekologiczny ${ }^{55}$. Wpływ na jego wyposażenie miał Krzyżanowski, który pisał: „Siostry urządzają prowizoryczną salkę porodową z byłych mebli lecznicowych. W sobotę wybierałem sobie $\mathrm{z}$ dwoma siostrami z gruzów Lecznicy Nadmorskiej to, co stare i zużyte. Czynność trochę przykra, bo widziało się tam ruch i placówkę żywą, a teraz wszystko odrapane i w gruzach. Satysfakcji żadnej nie miałem" ${ }^{56}$. Ceremonię otwarcia opisała lokalna prasa, nie bez znaczenia był tu udział biskupa chełmińskiego Stanisława Okoniewskiego, notabene często odwiedzającego Gdynię. Po kameralnej mszy św. w pobliskiej kaplicy duchowny w asyście oficjeli poświęcił skrzydło placówki, które mieściło wspomniany oddział. Jak oceniano pawilon „[...] przedstawia się bardz[o] pięknie i wyposażony jest w najnowsze urządzenia techniki lekarskiej i hygeny tak że pacjentki z pełnym zaufaniem mogą korzystać z jego usług tem więcej, że opieka lekarska i pielęgnacja chorych jest jak najlepsza" ${ }^{57}$.

Opinia pacjentów i mieszkańców dotycząca Lecznicy Nadmorskiej mogła być zupełnie różna od tej wyrobionej przez urzędników. Co prawda, „Dziennik Gdyński”

54 Pismo lekarza powiatowego Józefa Stankiewicza do PUW, 6 października 1933 r., APB, PUW, sygn. 4/11692, brak paginacji.

55 Kronika Domu Sióstr Miłosierdzia, 9.

56 Krzyżanowski, Krzyżanowska-Mierzewska, Według ojca, według córki, 116.

57 „Poświęcenie nowego szpitala w Gdyni”, Dziennik Gdyński 99, 1 października 1934 r., s. 4. 
donosił o rozkładających się zwłokach kobiety i dziecka w kostnicy, co - jak podkreślano - nie powinno mieć miejsca ${ }^{58}$. Jednak w tym samym tytule odnajdujemy podziękowanie kierowane do Mikicińskiego „za opiekę i pomyślnie wykonaną operację brzuszną, oraz całemu personelowi, który swoją troskliwą pielęgnacją przyczynił się do szybkiego mego wyzdrowienia" ${ }^{59}$. Pozytywne treści wynikają z ciekawego skądinąd apelu pacjentów Lecznicy Nadmorskiej, wystosowanego na łamach prasy do, cytując, „gdyńszczan”. Dotyczył on ufundowania biblioteczki przyszpitalnej, o którą starali się chorzy, podkreślający nudę pobytu w szpitalu. Sposobem na nią miała być „[... ] książka - ta nierozerwalna przyjaciółka każdego człowieka, a szczególnie chorego" ${ }^{60}$. Biorąc pod uwagę, że pobyt w szpitalu trwał zwykle długo, nie można dziwić się desperacji pacjentów. Ci zaś podkreślali „[...] dobre stosunki, jakie panują pod każdym względem, jeżeli chodzi o leczenie i opiekę [...]"61.

Dzięki unikatowemu albumowi z fotografiami autorstwa Z.K. Tustanowskiego wiemy, że dla zabicia nudy grywano w karty. Nie była to jednak rozrywka mogąca zaspokoić wszystkie gusta. Brak informacji o innych zajęciach pacjentów, zresztą na zdjęciach trudno zaobserwować jakąkolwiek znaczniejszą ich aktywność. Mogło to wynikać ze specyfiki placówki, w dużej części koncentrującej się na chirurgii operacyjnej oraz położnictwie. Chorych widać głównie leżących, w salach wieloosobowych, a kadry są pozowane. Kilka ujęć przybliża przebieg wykonywanych zabiegów, widać na nich stroje personelu, specjalistyczny sprzęt i szpitalne meble. Przed wejściem do budynku pozwolili się uchwycić również Bobkowski i Mikiciński. Fotografie są ciekawym materiałem źródłowym do historii lecznictwa, wymagającym dokładnego opracowania. To tzw. stykówki, wywoływane niejako poglądowo i odpowiadające wymiarowi kliszy (w skali 1:1), co utrudnia wychwycenie szczegółów. Sam album, stanowiący własność prywatną, jest i tak wyjątkowy, gdyż dotąd znane były jedynie pojedyncze zdjęcia bryły budynku. Na 14 zajętych kartach znajduje się łącznie 119 całych zdjęć i cztery fragmenty ${ }^{62}$. Ich tematyka wiąże się z dwoma miejscami zatrudnienia - najpierw jako lekarza okrętowego na s/s Warszawa przez Polsko-Brytyjskie Towarzystwo Okrętowe (15 lipca 1929 - 31 sierpnia 1930 r.), później zaś w Lecznicy Nadmorskiej (1 września 1930 - 31 marca 1931 r.). Jak wspominał lekarz, klimat mu nie służył, w związku z czym opuścił Wybrzeże ${ }^{63}$. Mimo stosunkowo krótkiego pobytu zawdzięczmy mu fotograficzny zapis szpitalnej codzienności.

58 „Trupiarnia - cmentarzem”, Dziennik Gdyński 135, 15 czerwca 1932 r., s. 3.

59 M. Jędrzejczakowa, „Podziękowanie”, Dziennik Gdyński, 59, 12 marca 1930 r., s. 5.

60 Chorzy, „Głosy z Lecznicy Nadmorskiej”, Dziennik Gdyński 55, 8 marca 1931 r., s. 3. Wyraźnie dotykała (wręcz trawiła) ich jedynie nuda, co powtarzane jest w apelu prasowym.

${ }_{61}$ Chorzy, „Głosy”, 3.

${ }_{62}$ W październiku 2019 r. syn Zbigniewa Tustanowskiego zaoferował przekazanie albumu do Muzeum Miasta Gdyni jako darowizny. W czasie przygotowywania niniejszego artykułu trwały dopiero procedury przyjęcia, stąd obiekt i jego zawartość opisane są jako własność prywatna.

63 Wiadomości elektroniczne od syna dra Tustanowskiego do autora, 26 i 30 października 2019 r. 


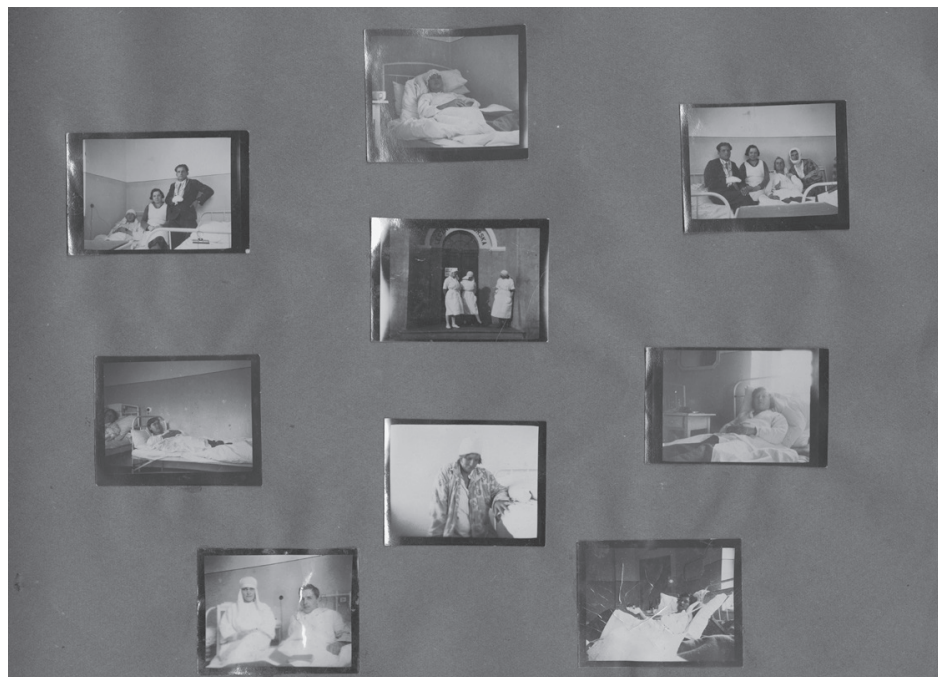

Il 5. Karta z albumu ze zdjęciami autorstwa Zbigniewa

Tustanowskiego, 1930-1931, własność prywatna

Po likwidacji Lecznicy Mikiciński i Bobkowski nadal praktykowali w Gdyni, i to z powodzeniem. W czerwcu 1933 r. uznany w Gdyni architekt Stanisław Ziołowski przygotował dla Mikicińskiego nowoczesny i można założyć, że nie tani projekt kamienicy przy ul. 10 Lutego, którą wybudowano w ciągu następnych dwóch lat ${ }^{64}$. Byli wspólnicy nie rozliczyli się prawdopodobnie ze spraw Lecznicy. Placówka figurowała na liście dłużników z tytułu wywozu nieczystości jeszcze w $1934 \mathrm{r}^{65}$

Lecznica Nadmorska to niezwykle ciekawy przykład prywatnej inicjatywy biznesowej na polu opieki zdrowotnej. Formuła jej funkcjonowania nie była w Gdyni nowatorska, wszak główny szpital rosnącego miasta był prowadzony przez zgromadzenie zakonne, czyli również na zasadach zakładu niepublicznego. Podobnie gabinety miejscowych (przez zatrudnienie, bo faktycznie napływowych) lekarzy niejednokrotnie pełniły rolę poradni dla pacjentów ubezpieczonych. Wiązało się to z brakiem odpowiednich placówek medycznych i infrastruktury, która mogłaby służyć powstającej służbie zdrowia. Inwestorzy placówki - lekarze Stanisław Bobkowski i Miron Mikiciński - świetnie wykorzystali zapotrzebowanie, szybko oferując profesjonalną pomoc rannym i chorym. Dołączając do miejscowego „stanu lekarskiego", stali się jego barwnymi postaciami. Rola kontaktów towarzyskich w skutecznym prowadzeniu interesu była tu nieoceniona. Trudno jednoznacznie wskazać powody, dla których Lecznica nie przetrwała na rynku.

${ }^{64}$ Maria Jolanta Sołtysik, Na styku dwóch epok. Architektura gdyńskich kamienic okresu międzywojennego (Gdynia: Wydawnictwo Alter Ego, 2003), 159.

${ }_{65}$ Zakład Oczyszczania Miasta w Gdyni, Sprawozdanie rachunkowe za rok 1933/34, [1934], APGoG, KRz, sygn. 682/1516, s. 44-55. 
Mogło to wynikać zarówno z rachunku ekonomicznego, jak i z obserwowanej zależności prywatno-publicznej. Pozycja Bobkowskiego w podwójnej roli, decyzyjnego pracownika Kasy Chorych i udziałowca dotowanej kliniki, mogła kłuć w oczy i wzbudzać niechęć w środowisku lekarzy i władz samorządowych. Zachowane dokumenty sprawy nie rozstrzygają. Niezależnie od powyższego przez niecałe trzy lata funkcjonowania opieką objęto około 2500 pacjentów ${ }^{66}$, którzy uniknęli poszukiwania pomocy w zamiejscowych placówkach. Tym samym bilans Lecznicy należy uznać za jednoznacznie dodatni.

\section{Marcin Szerle}

\section{The Seaside Clinic in Gdynia as an example of hospital private initiative in the interwar period. Case study}

The article introduces the short history of a private clinic operating in Gdynia of the interwar amid the broader grounds of the health care system of the time.

Starting with the definition of a clinic - a facility limited in its care range to a selected group of diseases, the text describes the circumstances of establishing such a mini hospital in the growing town of Gdynia. This Baltic shore village had become a place of significant investment since 1920 - the construction of a port serving the reborn country. In a short period of time subsequent harbours were built: naval, fishing and trade with a thriving and modern city alongside them. The scale of transformations as well as the social processes involved, including a massive flow of population meant that the administration at various levels did not keep up with the construction of necessary infrastructure. Shortages in terms of health care and treatment, housing development or education were covered by private initiatives. There was prosperity for such undertakings in Gdynia. Two visiting doctors had also decided to take advantage of it, namely Miron Mikiciński and Stanisław Bobkowski, who having observed the necessities of the city established there in 1929 a clinic for surgical, gynaecological and midwifery cases.

It was in a rented villa close to the very centre of the town where a facility with 36 beds was established, whose financial maintenance was supported by local authorities. The undertaken public and private venture was indispensable for securing immediate surgical cases, while at the same time giving the inhabitants the possibility of having their children delivered in proper conditions, among others. The clinic would quickly take over the "market" in the scope of female health and pregnancy pathology. Still, they treated patients insured in the public Health Maintenance organisation (Kasa Chorych), which constituted a source of additional income. It would trigger controversies, since the chief medical doctor of the insurance institution was at the same time an investor of the clinic. Thus, despite its broad range of activities, operations of the facility would raise doubts or

66 Dane bez $1932 \mathrm{r}$. 
even were critically judged. In nearly three years after its opening, facing an absence of agreement while striking a new deal with local authorities, the owners closed down the clinic. Its equipment was then bought by the city authorities and ended up in two hospitals in Gdynia, the doctors - owners and employees, with one exception, remained in Gdynia, successfully continuing their practice. After Zbigniew Tustanowski, the one doctor who had left the city, an extraordinary legacy remained, namely an album with photographs of the personnel, patients, the interiors and the inventory of the facility. From it, we learn of the everyday life of the hospital and of the backstage of functioning of that interesting place in the medical history of Gdynia. 